\title{
THE PROJECT OF CPEC: BENEFITS AND DRAWBACKS FOR GILGIT-BALTISTAN
}

* Muhammad Ismail, Researcher, Department of Political Science, Federal Urdu University, Karachi

ismail.hamza@ymail.com

\begin{abstract}
Chine-Pakistan economic corridor (CPEC) is a game changer for the four provinces of Pakistan as well as for the regions of Gilgit-Baltistan and Azad Kashmir. It will become the main connective channel between both states through transport, industry, Power energy (electricity), promotion of trade and tourism. CPEC will be equally important for the central, south Asia and Middle East. This project will provide the opportunities to increased economic and strategic development in the country. Gilgit-Baltistan is bordering region between china and Pakistan. It connected both nations by Karakorum Highway which is started from Khunjrab pass in the gate way of Gilgit-Baltistan and include in CPEC. It is passes through the mountains, ups and downs ways and covers 600 $\mathrm{km}$ in $(G B)$ region. The people of $G B$ have some apprehensions on unequal distributed of rights but government of Pakistan ensuring to the people of the region, that in this project they will receive equal rights like others provinces. This study intended to provide every aspect of one belt one route concept and its effects particularly on the beautiful northern region of Pakistan.
\end{abstract}

KEYWORDS: FANA, China-Pakistan Economic Corridor, Kashmir, Karakoram High Way, Pakistan, United Nations, Silk Route,

\section{INTRODUCTION}

Gilgit-Baltistan is the entranceway of CPEC which will open a sea channel for western bordering region of China through the Baluchistan's Gwadar coast locates at the Indian Ocean. (IIIIV). The Peoples of region got freedom from the Kashmiri maharaja Hari Singh on the first November 1947, after they got freedom, the peoples of Gilgit-Baltistan willingly tied with the Pakistan on the basis of Islamic ideology and given a whole 


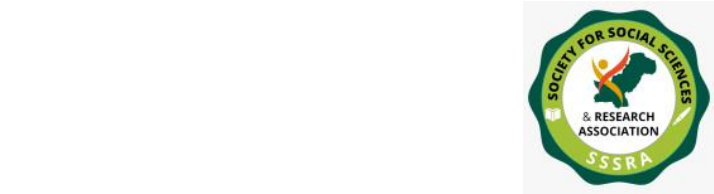

region as a gift to the father of nation Quaid-e-Azam. It previously known as FANA (Federally Administrated Northern Areas). The GB region primarily was the part of the former princely state of Jammu and Kashmir which after the partition immediately tied with Pakistan as an independent state during first November to 16 November 1947.

Gilgit-Baltistan united with Pakistan since independence and work under its management. GB was given self-governance on the 29 August 2009 by the order of president of Pakistan Asif Ali Zardari. This region comprises with ten districts with three divisions. It came into lime light with the declaration of the china-Pakistan Economic corridor. The prominence of northern region cannot be neglected because it is the entrance of CPEC and also the well-known fowl collar. The Karakorum highway (KKH) known as the $8^{\text {th }}$ wonder of the world because it was constructed on seven thousand feet above sea level on unbelievable ups and downs ways mountainous region of GB. It was built in 1969-78 to link china to the world by giving entrance to Arabian Sea. The CPEC project will uses the $\mathrm{KKH}$ with enlargement and transient along the mountains of the region. The location of GB is strategically vital for Pakistan, china, USA as well as for India. It is as significant today as it was in 1880s when (Tsar Empire of Russia occupied central Asian region and their officials approaches to Gilgit, and Hunza. Their arrival there was marked as the beginning of the great game. ( Beg, Baig, \& Khan, 2018). The KKH will be further developed and some new tracks will be built for swift transportation, in addition new bridges, passageways and railway tracks are also planned to build to connect both countries.

GB region shares its boundaries with China which resulting in an active trade conditions have stayed there since the existence of former silk route. Later china and Pakistan have signed many free trade agreements; the last Free Trade Agreement was signed between the two countries in 2006. (Athar, 2019). The division of CPEC associated scheme in all over Pakistan appears that so far the GB is going to gain nominal from this project. In the region there is no hydro power or industrials project and only one special economic region Magpoondas and fiber connection, yet these are not final decisions. After the 71 years, the constitution statues 


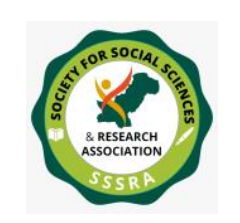

need to tackle by the UNO and the government of Pakistan, by the desires of the peoples Of FANA. The peoples of the region have no representation in parliament or senate of Pakistan. People of this region demanded that they should declare in constitution as the citizens of Pakistan and GB should become the fifth province of the country. The economic corridor has been very substantial for south and central Asia as well as very useful for the middles east countries. The corridor not only in benefit for china, but with it the world inter linked with Beijing by using land rout (Karakorum high way). In the case of Pakistan, the corridor has helpful to control the energy crises, water crises and enhance of economic development as well as job employments. Pakistan also will increase its trade with, china and the central Asian nations.

Pakistan does not register Gilgit-Baltistan as its official land in constitution, although the State has exercised its control in the region after the Independence. The GB is described as a region administer by Pakistan and is known as FANA (Federally Administrated Northern Area) in the Constitution (Bhattacharjee, 2015). The unequal distributions of rights or undefined the in constitutions statues of Gilgit-Baltistan will be dangerous for the huge project (62 billion \$) of CPEC. The Government of India also claimed that GB region is the part of India because it was the part of Indian held Kashmir before its independent status declaration and accession with Pakistan on first November 1947.

According to the government of Pakistan, the plan is expected to procure multiple changes in Regions in the field of infrastructure growth, building of road and hydro power projects and special zone in Gilgit. It would open corporate advancement prospects for the peoples of region and indeed will be a game changer for all.

\section{GEOGRAPHY OF GB REGION}

Northern area is surrounded physically among the great powers like china, India and Russia. It is situated in the three great mountain ranges of the world, the Himalayas, Karakorum, and hindukush. The GB region is covered nearly $72,971 \mathrm{Sq} \mathrm{km}$. It bordered with china in north, Indian in 


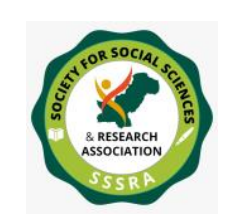

south, Afghanistan in west and the Khyber Pakhtunkhwa province of Pakistan in south west. This is a home of highest mountain ranges and peaks such as K2, the second highest peak, Nanga Parbat, Gasherbrum I, Broad peak, Masherbrum, Rakaposhi, and many others. GB region is bounded in the north by the Wakhan corridor Afghanistan.

The region connected with Xinjiang the independent Chinese state, Wakhan Corridor of Afghanistan, the Ladakh area of Indian taken Kashmir, Azad Jammu and Kashmir and Khyber-Pakhtunkhwa. Central Asia and the Tibet area of China are far-away neighbours. (Khan E. M., 2017). The region is a home of rare juncture of Asian gigantic continent, as it connects parts of west, central, and south Asia and china. The commercial linkage and proceedings establish with this region are particularly with china, Tajikistan and Afghanistan. GB provides passageway to the significant trading land broadening from west Asia and Africa for china. Therefore, GB is immensely significant for the world and global powers are seeking to entre and get their own benefits and attain strategic aspects.

\section{ADVANTAGES OF CPEC FOR THE REGION}

There are some gains of CPEC for the GB region as it is the Gate way for both Pakistan and China. There are some possible advantages $\backslash$ Benefits in future for the people of the region, such as;

- The corridor will be created $1 \%$ job opportunities for the peoples of Gilgit Baltistan.

- The region is the water store body for Pakistan it is also produces electricity for other provinces of Pakistan.

- CPEC will be significant for the peoples of Gilgit-Baltistan for the Optic Fiber connection.

- Through the CPEC created nine special economic Zones in all over Pakistan among them one economic Zone will be for this region which will constructed in Magpoondas area.

- Roads will be expanded in Gilgit-Baltistan and it will be very easy and short way to Pandi to Gilgit. 
- In future it cans be possible for train service began between China and Pakistan which would be vital for GB region because the railway track will be started from China to Gilgit to Gwadar port.

\section{RECOMPENSES ACCORDING TO GOVERNMENT OF PAKISTAN}

Government of Pakistan showing the future vision for the peoples of the region and according to them there are multiple benefits of CPEC for the region such as;

- At Magpoondas fruit processing industries, precious Gemstone cutting and polishing center, iron \& steel industry would be constructed in future.

- The subsidiary effect of the CPEC is obvious that GB is likely in the terms of commercial progress, energy generations, infrastructures of Road development and telecommunications.

- The connectivity through road and train plus internal city road will be laid to increased social and economic integration.

- The CPEC Road benefits to the local peoples to connect one district to other district to an easy way and faster.

- The future development is expected in the region as peoples are getting training or learning Chinese languages and professional skill.

- Due to the CPEC, both countries Pakistan and china will be given batter security to the region due to their own interest.

- Due to the CPEC and interest of both countries, ten years sectarians' conflict will be end by better security. (Sikander, 2019; Beg, Baig, \& Khan, 2018)

- The Karakorum highway expansion occur because of CPEC, the constructing of Gilgit to Chitral Road, establishment of the phandar hydropower project in Ghizer, Karakoram international university hydro power project in Gilgit city.

- The Pakistan government constructed the Diamer_Bhasha dam and china-Pakistan optical fiber project. 
- Through the CPEC in future the Bunji-Roundo Dam will be build and it produces electricity and water to the Pakistan. (Khan N. N., 2019)

- The Government of Pakistan claims that the project would create employment opportunities for 1.8 million peoples in GilgitBaltistan

\section{DRAWBACKS OF CPEC FOR GILGIT-BALTISTAN}

There are number of drawbacks of CPEC for the GB region in opinion of local peoples such as;

- The local people of Gilgit Baltistan can't trust on the government of Pakistan.

- A war can be possible between India, china, USA and Russia on GB region.

- A war between India and Pakistan will be possible in the region because also have a claim on the region.

- Cultural changes will increase and the Chinese culture will change the local cultural or might be finished it any time.

- Open access of the Chinese people can create a strong influence in the region which can create issues for locals.

- It can create the religious issues for the region because Chinese people are non -Muslim and can affect the religious emotions of the region.

- There is a danger possible migration of locales from Gilgit region.

- This region has no politico-constructional statues or fundamental rights, due to the disputed status in the United Nations resolution 1947\& 1948.

- People believed that Gilgit Baltistan facing serious environment issues like air pollution, melting of glacier because of CPEC with the short passage of time.

- Large amount of heavy vehicles transportation on a daily bases caused the various diseases like skin, increase of heat temperate and others. 
- Increase in soil erosion and waste disposal are the issues for the region of Gilgit-Baltistan.

- The plan of CPEC associated projects of the country show that the region is going to get very little from the huge project because so far no big hydro project or industry project is announced by the regime.

- The nine trade and industrial zones will be established under CPEC in the country and only one adding for the Gilgit-Baltistan had been establishing a CPEC economic zone.

- The people of region are in complete uncertainty and in a doubt which is based on the narrative created by one sector of society who were unable to see direct and indirect advantages of CPEC. The majority peoples of Gilgit Baltistan believe that, they will get nothing from the CPEC, no job and no economic development in the region because the government can't make a plan.

- The local nationalist movement against the CPEC due to the undefined statues of GB and unequal right given to the local people.

According to the Manzoor Parwana, the Nationalist leader of Gilgit Baltistan said;

"We are one of the three major parties to the project .China and Pakistan should consider Gilgit Baltistan the third party in the CPEC and given our shares as such. He said Gilgit Baltistan is a disputed territory and it is neither a part of China nor Pakistan. As the area has its own distinct cultural and historical identity, without including it in the CPEC project as a partner, none of the two countries." (Parwana, 2019).

Due to the CPEC most of the hotels, shops, market and business are already owned by non-local from different parts of Pakistan and locals believes that after the beginning of the project, the region will be more attracted by non locals, which is dangerous for locals; this will ultimately turn locals into minority in business. 


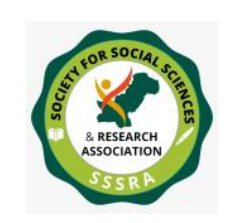

The 7000 trucks will passes through this region weakly. Emitting a large amount of carbon, and smoke gases as the government of Pakistan and Chinese will be lay railway trucks in this mountainous area by building a number of tunnels. This will caused future landslides and disturb the regions ecological balance, which is dangerous for the human, animals and plants.

Climate changes in the region will be causes migration from Punjab, KPK, Sindh into Gilgit-Baltistan and the result will be in the sectarian conflict. The local peoples fear that air pollution from the heavy transportation of china-Pakistan passing through GB would devastate the natural environment. The Chinese people are coming in Pakistan and in GB region cause to change of cultures and Islamic values as a result non-ethical values are born in these Islamic regions.

China transports $80 \%$ of its oil, through Strait of Malacca to Shanghai by sea and covers a distance of $16000 \mathrm{~km}$ in two or three months, whereas via CPEC it will cover $3218 \mathrm{~km}$, reducing down the shipment time to a few days.

Therefore, the local population demanded to the government to give the constitution rights and made it the fifth province of Pakistan, also demanded to give the equal rights in the CPEC like others provinces.

\section{CONCLUSION}

The China-Pakistan economic corridor is biggest project for the china and Pakistan but it is more in benefit for Beijing than Islamabad. China can do trade for all over the world by land route. It is a short and easy way to trade via Pakistan to the world. CPEC also provide another option to china to transports of 80 percent of its needed oil, passes by Karakorum high way instead of strait of Malacca to Shanghai which takes two or three month, whereas via CPEC, it will deliver in few days.

On the other side the locals looking towards government of Pakistan and china, hoping that benefits will be equal to the GB region as well. There 
are some advantages of the corridor for the region, as it is the heart line for the Pakistan and Chinese. The future of china-Pakistan economy and the disputed territory of Gilgit-Baltistan may be needed to define in the best way it needs to be underlined. GB have been indicating against the hostile treatment with their region for decades by Pakistan. Some demands like better rights, legal and political participation within the country, while others demands complete freedom. Regardless of Pakistani assertions to the divergent, the government's credentials of ventures in the local frugality still insufficient and inconsistent. Redundancy rates are high, leading to a migration and conflict of youngsters from the region to urban areas of country as well as to the Middle East and other parts of the world.

There is a need of rethinking and reorganizing of policies by the regime related with undefined issues which can be dangerous not only for the huge project but for the country. It is necessary to remove apprehensions of locals regarding this project and create consensus. Locals anxious that the project can become a caused of war among the three big nuclear power states, India, china and Pakistan due to the international politics and World powers can provide support to the India to take action against the huge project. It is a right time to make fifth province and make amendment in the constitution, only than this huge project brings peace, economic prosperity, development and employments for the youth. 


\section{References:}

Athar, A. (2019, October). China-Pakistan Economic Corridor: Benefits and Drawbacks for Gilgit-Baltistan. (R. S. University, Interviewer) Islambad, Pakistan.

Beg, S., Baig, T., \& Khan, A. (2018, April 2 ). Impact of China-Pakistan Economic Corridor (CPEC) on Human Security and the Role of GilgitBaltistan. Global Social Sciences Review (GSSR), 3(4), 17-30.

Bhattacharjee, D. (2015). Gilgit Baltistan, China and Pakistan. Indian Council of World Affairs.

Khan, E. M. (2017). CONSTITUTIONAL STATUS OF GILGITBALTISTAN:AN ISSUE OF HUMAN SECURITY. MARGALLA PAPERS.

Khan, N. N. (2019, November). CPEC: Benafits and Drawbacks for Gilgit-Baltistan. (M. G.-B. Assembly, Interviewer)

Parwana, M. (2019). CPEC: Benifits and Drawbacks for Gilgit-Baltistan. (N. l. Baltistan, Interviewer)

Sikander, A. (2019, Septmber). CPEC: Benefits and Drawbacks for GilgitBaltistan. Gilgit, Pakistan. 